Canadian Science Publishing

Canadian Journal of Earth Sciences Revue canadienne des sciences de la Terre

\title{
Lithostratigraphy and sedimentary environment of the Precambrian Kushk Series of Central Iran
}

\begin{tabular}{|r|l|}
\hline Journal: & Canadian Journal of Earth Sciences \\
\hline Manuscript ID & cjes-2017-0234.R2 \\
\hline Danuscript Type: & Article \\
\hline Complete List of Authors: & $\begin{array}{l}\text { Vaziri, Seyed Hamid; Islamic Azad University Tehran North Branch, } \\
\text { Department of Geology } \\
\text { Laflamme, Marc; University of Toronto - Mississauga, Department of } \\
\text { Chemical and Physical Sciences }\end{array}$ \\
\hline Keyword: & Ediacaran, carbonate, siliciclastic, Bafq, Behabad \\
\hline $\begin{array}{r}\text { Is the invited manuscript for } \\
\text { consideration in a Special } \\
\text { Issue? : }\end{array}$ & N/A \\
\hline & \\
\hline
\end{tabular}

SCHOLARONE ${ }^{m}$

Manuscripts 


\title{
Lithostratigraphy and sedimentary environment of the Precambrian Kushk Series of Central Iran
}

\author{
Seyed Hamid Vaziri and Marc Laflamme
}

S.H. Vaziri: Department of Geology, North Tehran Branch, Islamic Azad University, P.O. Box 19585851, Tehran, Iran.

M. Laflamme: Department of Chemical and Physical Sciences, University of Toronto Mississauga, 3350 Mississauga Road, Mississauga, Ontario, L5L 1C6, Canada.

Corresponding author: Seyed Hamid Vaziri (email: h_vaziri@iau-tnb.ac.ir) 


\begin{abstract}
The Kushk Series is a distinctive late Ediacaran succession occurring in the Bafq and Behabad regions of central Iran that has yielded an extensive community of diverse Ediacara biota, including several Precambrian (Chuaria) and Ediacaran (Cloudina, Corumbella) index fossils. The Kushk Series reaches a thickness of up to $518 \mathrm{~m}$ and consists of shallow to deep subtidal deposits along a homoclinal carbonate ramp during a transgression/regression cycle. These deposits accumulated as part of an extensional rift basin complex resulting from the opening of the Proto-Paleotethys Ocean in northeastern Gondwana. Latest Ediacaran fossils occur in the deep-water calcareous marine shales, and represent a thriving community at the dawn of animal life.
\end{abstract}

Keywords: Ediacaran, carbonate, siliciclastic, Bafq, Behabad.

\title{
Introduction
}

During Ediacaran and Cambrian, Iran was part of a thermally subsiding passive margin that was formed through late Proterozoic rifting of northwestern Gondwana (Berberian and King 1981; Lasemi 2001; Lasemi and Amin-Rasouli 2016). Shallow-marine (mostly carbonates) and fluviodeltaic sediments were deposited over a vast area, from northern Arabia in the southeast to the Alborz region in northern Iran, forming the northern passive paleocontinental margin of Gondwana (Berberian and King 1981; Lasemi 2001; Berberian 2014, Lasemi and Amin-Rasouli 2016). Facies and sequence stratigraphic studies of the upper Neoproterozoic through Paleozoic successions in the region (Lasemi 2001) suggest that Iran and northern Arabia were connected until their breakup in the early Permian (Lasemi and Amin-Rasouli 2016). 
The Ediacaran Kushk Series in the Bafq and Behabad regions of central Iran (Fig. 1) lies along the eastern margin of the Yazd Block. These units represent the oldest deposits in central Iran, and consist of a mixture of siliciclastic, volcanic, and carbonate rocks (Hamdi 1995). The Kushk Series is extensive and well exposed in the region, with a measured thickness of more than 500 $\mathrm{m}$ in some areas, and is known for its black shales that host economically viable lead-zinc deposits (Yaghubpur and Mehrabi 1997; Rajabi et al. 2014; Rajabi et al. 2012a). The Kushk Series represents a relatively deep-water paleo-environment when compared to the northern fossiliferous Soltanieh Formation (Stöcklin et al. 1964; Shahkarami et al. 2017a; Shahkarami et al. 2017b), allowing for comparisons of fossil diversity and community ecology across a major bathymetric divide across the Ediacaran-Cambrian boundary.

Extensive field seasons in 2014 and 2016 allowed for detailed stratigraphic and sedimentological studies of the Kushk Series in Kushk and Chahmir areas. Dozens of samples were collected from each section to allow for petrographic studies and detailed descriptions of the facies and implied depositional environments. Furthermore, over 250 fossil specimens were collected from the argillaceous shales of sub-unit 6 , showcasing a diverse animal community from the Ediacaran to Cambrian transition in Iran (Vaziri et al. 2018).

\section{Geological setting}

The Kushk Series crops out across a large area of the western margin of the Lut Block and the eastern margin of the Central Iranian Yazd Block (Fig. 1). These units were initially described as a part of the Rizu Series (Stöcklin 1961, 1968, 1972, 1986); however, subsequent investigations have demonstrated that they represent a temporally and lithologically distinct unit (Hamdi and Zhiwen 1992). 
Geochronological constraints of the Kushk Series are sparse. Four ${ }^{207} \mathrm{~Pb} /{ }^{206} \mathrm{~Pb}$ dates have been reported from the Kushk area: 595, 690 and 715 Ma (all \pm 120 Ma; Huckriede et al. 1962) and $581 \pm 8.6 \mathrm{Ma}$ (Vickers-Rich et al. 2017), while the Chahmir area has a single ${ }^{207} \mathrm{~Pb} /{ }^{206} \mathrm{~Pb}$ date of $540.7 \pm 4.8 \mathrm{Ma}$ (Vickers-Rich et al. 2017). Huckriede et al. (1962) used three sulfide lead-zinc ores for radiometric measurements of the $\mathrm{Pb}$ lead isotopes. Vickers-Rich et al. (2017) analyzed zircon grains (a sandstone from the Kushk area and a mudstone from the Chahmir area) for U, Th, and $\mathrm{Pb}$ isotopes by LA-SF ICP-MS techniques.

Late Ediacaran body fossils, including Permedusites changazensis Hahn and Pflug 1980, have previously been reported from the shale deposits (Hahn and Pflug 1980; Glaessner 1984; Hamdi 1995). However recent taxonomic and taphonomic studies put into question the reliability of the taxonomic assignments of most other Ediacaran body fossils reported from central Iran (see Vickers-Rich et al. 2017; Vaziri et al. 2018). The recent discovery of the Proterozoic index fossil Chuaria, and classic terminal-Ediacaran index fossils Cloudina, and Corumbella (Vaziri et al. 2018), support Hamdi and Zhiwen (1992) in assigning a latest Ediacaran (to earliest Cambrian) age.

\section{Results}

\section{Lithostratigraphy}

The Kushk Series reaches a total thickness of $518 \mathrm{~m}$ in the Kushk area (Fig. 1: coordinates: $\left.31^{\circ} 45^{\prime} 30^{\prime \prime} \mathrm{N} ; 55^{\circ} 45^{\prime} 46^{\prime \prime} \mathrm{E}\right)$, however its lowermost boundary is not exposed and the uppermost boundary is faulted with the lower Cambrian Hashem Formation (Vaziri et al. 2018). The Kushk Series is divided into 13 sub-units consisting of rhyolite, microdiorite, tuff, shale, sandy dolomitic limestone, dolomite, and sandstone intervals (Fig. 2). Coeval sections in the Chahmir area (Behabad; co-ordinates: $\left.31^{\circ} 38^{\prime} 38.8^{\prime \prime} \mathrm{N} ; 56^{\circ} 02^{\prime} 27.5^{\prime \prime} \mathrm{E}\right)$ are much thinner $(\sim 175 \mathrm{~m})$, and 
consist of black calcareous shale rich in organic matter, siliceous tuff, fossiliferous siltstone, and shale, and only preserve sub-units 5, 6 and 9 (Fig. 2). The 13 sub-units in the Kushk area are as follows (from bottom to top; Fig. 2):

1: Gray porphyritic rhyolite (13.2 m; Fig. 3b, c).

2: Yellow, thick- to thin-bedded sandy dolomitic limestone (8 m; Fig. 3b, d, e).

3: Black, thin-bedded calcareous shale with abundant white quartz veins (9.5 m; Fig. 3d).

4: Light-gray microdiorite (3.1 m; Fig. 3d, f).

5: Black, thin-bedded calcareous shale containing organic matter, horizontal trace fossils and pyrite (68.6 m; Fig. 3g, Fig. 4a, b). These shales are the host rock for lead-zinc deposits (Fig. 3a, d, g, Fig. 4a, Fig. 6a, b, g). In the Chahmir area, sub-unit 5 consists of tuffaceous shale, calcareous nodular pyritic shale, mudstone, and crystallized tuff (120 m; Fig. 2, Fig. 6a-c).

6: Gray, thin-bedded argillaceous shale $(30 \mathrm{~m})$ with intercalation of gray, medium-bedded sandstone (containing sponge and horizontal trace fossils), some massive sulfide mineralization with intercalations of pyrite, and green to brown tuff (Fig. 4c-f, Fig. 6d-f). Subunit 6 is exposed in the Kushk area (Kushk mine site, Dargazin (Chahgaz) and Wedge localities) and in the Chahmir and Darehdehu areas. Sub-unit 6 also contains a diverse assemblage of Ediacara biota including Kuckaraukia, Persimedusites changazensis, Cloudina, Chuaria, Corumbella, newly named Kimberella persii and Gibbavasis kushkii, in addition to unidentified Erniettomorpha, Rangeomorpha and numerous tubular organisms (Vaziri et al. 2018). This thriving Ediacaran community is much more diverse than typical latest Ediacaran systems (Darroch et al. 2015, 2016) and confirms a latest Ediacaran age (Nama-Assemblage 2545-541 Ma; Vaziri et al. 2018). This sub-unit can be correlated with the Lower Shale 
Member (Chopoqlu Shale) of the Soltanieh Formation (Stöcklin et al. 1964) in northern Iran which contains Ediacaran fossils such as Chuaria, Tawuia and Vendotaenia (Hamdi 1995; Jafari et al. 2007). At the Kushk area (Wedge locality), sub-unit 6 consists of grey argillaceous shale and sandstone with intercalation of tuff and dolomitic tuff (Fig. 4e), and in the Chahmir area it consists of grey, thin-bedded siltstone and argillaceous shale with intercalation of tuff and very thin-bedded mudstone (30 m; Fig. 2, Fig. 6d, e).

7: Red, thin-bedded argillaceous siliceous siltstone (2 m; Fig. 4g, h).

8: Alternating light-brown, medium-and thin-bedded dolomite and thin-bedded tuffaceous shale (15 m; Fig. 5a, b).

9: Green massive tuff (14 m; Fig. 5a, c, d). This sub-unit in the Chahmir area consists of green to gray, thin-bedded siliceous tuff (5 m; Fig. 2, Fig. 6g, h).

10: Alternating light-gray, medium-bedded dolomite and green thin-bedded tuffaceous shale (11.6 m; Fig. 5a, c, e, f).

11: Light-gray, medium-to thick-bedded dolomite with chert bands and calcite veins ( $24 \mathrm{~m}$; Fig. 5g, h).

12: Light-gray, thick-to very thick-bedded dolomite (30 m; Fig. 7a, b).

13: Alternating light-cream, massive rhyolite and green rhyolitic to rhyodacitic tuff with quartz veins impregnated with iron oxide (284 m; Fig. 7c-h). 


\section{Facies analysis and depositional environments}

The sub-units of the Kushk Series consist of four main facies that can be divided into two facies associations: a) Shallow subtidal facies association (FA1) consisting of facies F1, F2, and F3, and b) Deep subtidal facies (F4) association (FA2) (Fig. 8):

\section{a. Shallow Subtidal Facies Association (FA1)}

Facies association 1 is laterally extensive and consists of shallow water carbonate facies (sandy dolomitic limestone and dolomite) and siliciclastic-carbonate facies (siltstone, shale, tuff, and dolomite) that were deposited in an inner-mid ramp setting (sub-units $2,7-12 ; 105 \mathrm{~m}$ ). The major depositional processes were a seaward progradation of the inner sand belt and storm transport of shoreface sand out to the deeper ramp (Tucker 1985). This facies association includes three main facies:

\section{F1. Sandy Crystalline Dolomitic Limestone Facies (sub-unit 2; 8 m)}

This facies is a shallow-marine carbonate that contains $10 \%$ fine to coarse-grained monocrystalline and polycrystalline quartz, and various lithoclasts (e.g. volcanic fragments; Fig. 3b, d, e). This facies shows evidence of an overall deepening trend, such as bed layer thinning (thick to thin beds) resulting in a gradual change to thin-bedded shales in sub-unit 3, which may represent the onset of a transgressive systems tract (TST).

\section{F2. Siliciclastic-Carbonate Facies (sub-units 7-10; 43 m)}

This facies consists of a series of argillaceous siliceous siltstone, tuffaceous shale, medium crystalline siliceous dolomite and dolomitized argillaceous crystalline tuff 
containing mainly calcareous textures (Fig. 4g, h, Fig. 5a-f). This facies shows a series of shallowing parasequences resulting in changes to mineralogy and bed thickness (shale to dolomite, thin to thick beds) and are likely indicative of a shallow open-marine setting deposited as part of an early highstand systems tract (HST).

\section{F3. Crystalline Siliceous Dolomite Facies (sub-units 11 and 12; 54 m)}

This facies is consistent with a carbonate ramp setting (Fig. 5g, h, Fig. 7a, b) that is mostly composed of medium- to very thick-bedded, fine to medium-grained, crystalline siliceous dolomite with chert bands at its base. As with F2, F3 represents a series of shallowing-upwards parasequences suggestive of a shallow open marine facies deposited as part of a late highstand systems tract (HST).

\section{b. Deep Subtidal Facies Association (FA2)}

This facies association includes sub-units 3, 5, and $6(110 \mathrm{~m})$ and consists of a deep-water siliciclastic facies (siltstone, mudstone, sandstone, and shale) that was likely deposited in an outer ramp setting.

\section{F4. Siliciclastic facies (sub-units 3, 5 \& 6; 110 m)}

Overlying the lower carbonate facies is a thick accumulation of fine-grained black to light-gray calcareous to argillaceous shale with intercalations of fine-grained and thinbedded sandstone (sub-unit 6) that are rich in organic matter and contain horizontal trace fossils (Fig. 3a, d, g, Fig. 4a-f, Fig. 6a-f). Sediments fine and beds thin up section, and are finely laminated. The black coloration of the shales is attributed to the presence of very fine-grained iron monosulfide minerals (Berner 1984). The dark-black nature of the 
shale, combined with the presence of pyrite, both indicate the likelihood of reducing conditions, whereas the absence of grains, textures, and sedimentary structures typical of a shallow carbonate platform suggest sedimentation in a deep, open-marine basin as part of a transgressive systems tract (TST).

\section{Discussion}

Iran formed part of the northern margin of Gondwana from the late Precambrian to middle Paleozoic. Tectonic events that occurred around the Iranian Plate margins are related to the rifting processes of Gondwana and subsequent collisions with the Arabian plate (Alavi 2004). For example, the fragmentation of the northern margin of Gondwana was marked by increased magmatic activity (550-500 Ma; Turniak et al. 2000; Burda and Klötzli 2011), and Neoproterozoic ( 950-620 Ma) arc magmatism likely resulted from the accretion of Iran to the northern part of Gondwana (Husseini 1989; Berberian and King 1981). This was followed by the expansion of the Iranian crust through periodic epirogenic movements and rifting, leading to the deposition of volcanic rhyolites, basalts and andesites, tuffs and granites (Nabavi 1976; Berberian and King 1981; Samani 1992; Alavi and Amidi, 1968).

The Neoproterozoic successions in southern, central, and northern Iran are indicative of a failed rift system possibly related to the major Tethys rift that runs roughly parallel to the present Alborz region in northern Iran (Lasemi 2001). The late Precambrian alkali-volcanic rocks presumably developed during the rifting of the Iranian Plate, forming the sedimentary basins in which these sections accumulated (Berberian and King 1981). In the late Precambrian and early Cambrian, lithofacies show both synrift and post-rift sediment deposition within the ProtoPaleotethys basin (Lasemi 2001). The extensive accumulations of rhyolite, microdiorite and tuff, 
combined with shallow marine carbonate strata and deep-water calcareous marine shales in the Kushk Series (Central Iran), suggests that the Kushk basin may have represented an extensional rift basin related to the opening of the Proto-Paleotethys Ocean (Lasemi 2001) in northeastern Gondwana (Fig. 9).

The Kushk and Chahmir areas in central Iran are part of the Zarigan-Chahmir basin that is located in the southern part of a crustal domain known as "the Central Iranian Microcontinent", at the northwestern margin of Gondwana. This basin is bounded by the Kuhbanan Fault to the east and the Posht-e-Badam Fault to the west (Gibbs 1976; Förster and Jafarzadeh 1994; Rajabi 2008; Rajabi et al. 2012b), and is also known as the "Bafq mining district", which hosts economically important mineral deposits such as lead-zinc sedimentary-exhalative type deposits (Rajabi et al. 2014; Rajabi et al. 2012a). The opening of the Zarigan-Chahmir basin resulted from the breakup of the Central Iranian Microcontinent in the late Neoproterozoic to early Cambrian, due to the back-arc rifting of the continental margin, which occurred coeval with the convergence of the Proto-Paleotethys along the continental margin (Rajabi et al. 2014). The Kushk deposit was classified as a Kuroko-type volcanogenic massive sulphide deposit (cf. Sato 1973; Gibbs 1976). On the basis of the occurrence of exhalative hydrothermal features such as laminated sulphide textures, a SEDEX model was proposed by Mehrabi (1991) and Yaghubpur and Mehrabi (1997), who suggested an intra-continental rift setting for the Kushk deposits. Rajabi (2008) further proposed that the formation of SEDEX deposits in this basin was related to the evolution of an extensional continental margin in a back-arc environment that affected the Central Iranian Microcontinent.

The Kushk Series in Kushk and Chahmir areas is in many ways unique when compared to other age-equivalent sections. It consists of shallow and deep subtidal deposits along a homoclinal 
carbonate ramp during a transgression/regression cycle (Fig. 10). Shallow marine carbonate strata (F1) followed by the deposition of deep-water calcareous marine shales (F4) that contain trace fossils and abundant Ediacaran body fossils (Vaziri et al. 2018) represents a transgressive sedimentary cycle in response to deepening of the sedimentary basin. These strata are in turn overlain by siliciclastic-carbonate facies (F2) and carbonate platform facies (F3) likely deposited in a shallow, open marine environment during a presumed sea-level drop. In contrast, the Ediacaran Rizu, Desu, and Ravar series, and Derin Formation of central Iran consist mainly of shallow-marine continental margin and evaporite deposits (Aghanabati 2004; Navabi 1978; Alavi-Naini 2009) that lack Ediacaran fossils.

In the North, the age-equivalent Soltanieh Formation (Hamdi et al. 1989; Hamdi 1995) has been interpreted as a shallowing upwards epicontinental platform (homoclinal ramp), progressing from a coastal plain, to tidal flat, lagoon, barrier, and open marine shelf (Mirab-Shabestary 1994; Ansari 2001; Lasemi 2001; Jafari 2008; Shahkarami et al. 2017a). Members 1 and 2 of the Soltanieh Formation consist of shallow-water carbonates and shales (Chopoqlu Shale) also contain Ediacaran fossils (Hamdi 1995; Jafari et al. 2007) similar (albeit not identical) to those found in the deep-water shales (sub-unit 6) of the Kushk Series (Vickers-Rich et al. 2017; Vaziri et al. 2018). Importantly, many of the newly discovered taxa reported by Vaziri and colleagues (2018) have a global distribution, with known examples from southwestern USA and China, suggesting a biogeographic link between Central Iran and elsewhere that must be explored in more detail. 


\section{Conclusions}

The Late Ediacaran Kushk Series consists of shallow carbonate and deep siliciclastic facies, which resulted from a transgression-regression sequence. The detailed study of the Kushk Series indicates a set of siliciclastic and carbonate facies which were deposited in a homoclinal ramp setting (Fig. 10). Lower carbonate facies were deposited in a shallow carbonate platform during a relative sea-level lowstand while upper carbonate facies were deposited in a shallow open marine environment during a relative sea-level highstand in an inner-mid ramp setting. Siliciclastic facies include mainly black calcareous to argillaceous shales that were deposited in a deep open marine environment, in an outer ramp setting during a marine transgression.

\section{Acknowledgments}

Research supported by an Early Researcher Award (ERA), Natural Sciences and Engineering Research Council of Canada (NSERC) Discovery Grant (RGPIN 435402), and a Research and Scholarly Activity Fund to Laflamme. Thanks are extended to the Islamic Azad University to award a sabbatical to Vaziri at the University of Toronto Mississauga, Bafgh Mining Company and Iran Zinc Mines Development Company for providing research opportunity in the Kushk and Chahmir mineral areas, M.R. Majidifard (Research Institute for Earth Sciences, Geological Survey of Iran) for discussion and assistance in the field, M.M. Zand, H. Omidi and A. Shariati (Kushk Mine), and H. Zamani (Chahmir Mine) for useful information and companionship in the field, B. Hamdi (Geological Survey of Iran) for useful information on the geology of study areas, Y. Lasemi (Illinois State Geological Survey), D. Jahani and N. Kohansal Ghadimvand (Islamic Azad University, North Tehran Branch) for useful discussions on the facies and sedimentary environments of the region. Reviewers L.A. Buatois and E.F. Smith, in addition to Editor A. 
Polat and Associate Editor L. Beranek, provided constructive comments on the manuscript for which we are most thankful.

\section{References}

Aghanabati, S.A. 2004. Geology of Iran. Geological Survey of Iran Press, 586 p. [In Persian].

Alavi, M. 2004. Regional stratigraphy of the Zagros fold-thrust belt of Iran and its proforeland evolution. American Journal of Science, 304 (1), 1-20.

Alavi, M. and Amidi, M. 1968. Geology of western parts of Takab Quadrangle. Geological Survey of Iran, Geological note 49.

Alavi-Naini, M. 2009. Stratigraphy of Iran. Geological Survey of Iran Press, 507 p. [In Persian].

Ansari, F. 2001. Facies analysis and sedimentary environment of the Soltanieh Formation in the type area. M.Sc. thesis, Department of Geology, Islamic Azad University, North Tehran Branch, Tehran, 108 p. [In Persian].

Berberian, M. 2014. Earthquakes and Coseismic Surface Faulting on the Iranian Plateau; a Historical, Social, and Physical Approach: Amsterdam, Netherlands, Elsevier, Developments in Earth Surface Processes, 17, 638 p.

Berberian, M. and King, G.C.P. 1981. Towards a paleogeography and tectonic evolution of Iran: Canadian Journal of Earth Sciences, 18, 210-265, doi: 10.1139/e81-019.

Berner, R.A. 1984. Sedimentary pyrite formation: an update. Geochim. Comochim. Acta, 48: $605-615$.

Burda, J. and Klötzli, U. 2011. Pre-Variscan evolution of the Western Tatra Mountains: new insights from U-Pb zircon dating. Mineralogy and Petrology, 102, 99-115.

Darroch, S.A.F., Boag, T.H., Racicot, R.A., Tweedt, S., Mason, S.J., Erwin, D.H. and Laflamme, M. 2016. A mixed Ediacaran-metazoan assemblage from the Zaris sub-basin, Namibia. 
Palaeogeography, Palaeoclimatology, Palaeoecology, 459, 198-208.Förster, H. and Jafarzadeh, A. 1994. The Bafq mining district in central Iran - A highly mineralized Infracambrian volcanic field. Economic Geology, 89, 1697-1721.

Darroch, S.A.F., Sperling, E.A., Boag, T.H., Racicot, R.A., Mason, S.J., Morgan, A.S., Tweedt, S., Myrow, P., Johnston, D.T., Erwin, D.H. and Laflamme, M. 2015. Biotic replacement and mass extinction of the Ediacara Biota. The Royal Society Publication, B 282 (1814), 20151003.

Gibbs, A. 1976. Geology and genesis of the Bafq lead-zinc deposit. Mines and Metals B., 205220.

Glaessner, M.F. 1984. The Dawn of Animal Life. Cambridge University Press, 296 p.

Hahn, G. and Pflug, H.D. 1980. Ein neuer Medusen-Fund aus dem Jung-Präkambrium von Zentral-Iran. Senckenbergiana lethaea, 60(4/6): 449-461.

Hamdi, B. 1995. Sedimentary rocks of Precambrian-Cambrian in Iran, Geological Survey of Iran Press, no. 20, 353 p. [In Persian].

Hamdi, B. and Zhiwen, J. 1992. Paleozoic fossils from the Morad and Rizu series in Central Iran. Scientific Quarterly Journal of Geosciences, 1(4): 26-35 [In Persian with English abstract].

Huchriede, R., Kursten, M. and Venzlaff, H. 1962. Zur Geologie de Gebietes Zwischen Kerman und Sagand (Iran). Geol. Jb., Beih., 51: 1-197, Abb. 1-50, Taf. 1-10: Hannover.

Husseini, M.I. 1989. Tectonic and depositional model for the late Precambrian-Cambrian Arabian Plate. AAPG Bull., 73, 1117-31.

Jafari, S.M. 2008. Biostratigraphy of the Upper Precambrian and Cambrian-Ordovician sediments in quadrate of Takab. M.Sc. thesis, Department of Geology, Shahid Beheshti University, Tehran [In Persian]. 
Jafari, S.M., Shemirani, A. and Hamdi, B. 2007. Microbiostratigraphy of the Late Ediacaran to Ordovician in NW Iran (Takab area). Geological Society, London, Special Publications, 286, 433-437.

Kusky, T.M., Abdelsalam, M., Stern, R.J. and Tucker, R.D. 2003. Evolution of the East African and related orogens, and the assembly of Gondwana. Precambrian Research, 123, 81-85.

Lasemi, Y. 2001. Facies analysis, depositional environments, and sequence stratigraphy of the Upper Pre-Cambrian and Paleozoic rocks of Iran. Geological Survey of Iran Press, 78, 180 p. [In Persian].

Lasemi, Y. and Amin-Rasouli, H. 2016. The lower-middle Cambrian transition and the Sauk I-II unconformable boundary in Iran, a record of late early Cambrian global Hawke Bay regression. The Geological Society of America, Special Paper 525 Online First, 24 p., doi:10.1130/2016.2525 (10).

Mehrabi, B. 1991, Mineralogy and genesis of the Koushk (Bafq) Zn-Pb deposit. M.Sc. thesis, Department of Geology, Kharazmi University, Tehran, 185 p. [In Persian].

Mirab-Shabestari, Gh. 1994. Petrology and sedimentary environment of the equivalent rocks of Soltanieh Formation (Upper Precambrian-Lower Cambrian) in the Sarbandan (East Damavand) and Shahmirzad (North Semnan) areas. M.Sc. thesis, Department of Geology, Kharazmi University, Tehran, 173 p. [In Persian].

Navabi, M.H. 1978. Geological Quadrangle Map of Nain (scale 1:250.000), Geological Survey of Iran.

Rajabi, A. 2008. Geology, mineralogy, texture and structure, geochemistry and genesis of Chahmir $\mathrm{Zn}-\mathrm{Pb}$ deposit, south of Behabad, Yazd Province. M.Sc. thesis, Department of Geology, Tarbiat Modares University, Tehran, 300 p. [In Persian]. 
Rajabi, A., Canet, C., Rastad, E. and Alfonso, P. 2014. Basin evolution and stratigraphic correlation of sedimentary-exhalative $\mathrm{Zn}-\mathrm{Pb}$ deposits of the Early Cambrian ZariganChahmir Basin, Central Iran. Ore Geology Reviews, 64, 328-353.

Rajabi, A., Rastad, E., Alfonso, P. and Canet, C. 2012a. Geology, ore facies and sulfur isotopes of the Koushk vent-proximal sedimentary-exhalative deposit, Posht-e-Badam block, Central Iran. Int. Geological Review, 54 (14), 1635-1648.

Rajabi, A., Rastad, E. and Canet, C. 2012b. Metallogeny of Cretaceous carbonate-hosted Zn-Pb deposit of Iran: geotectonic setting and data integration for future mineral exploration. Int. Geological Review, 54 (14), 1649-1672.

Samani, B. 1992. Precambrian geology of Central Iran from point of view stratigraphy, magmatism and metamorphism. In proceeding of the 11 th symposium on Geosciences, Geological Survey of Iran, pp. 24-30 [In Persian].

Sato, T. 1973. A chloride complex model for Kuroko mineralization: Geochemical Journal, 7, $245-270$.

Shahkarami, S., Mángano, M.G. and Buatois, L.A. 2017a. Discriminating ecological and evolutionary controls during the Ediacaran-Cambrian transition: Trace fossils from the Soltanieh Formation of northern Iran. Palaeogeography, Palaeoclimatology, Palaeoecology, 476, 15-27.

Shahkarami, S., Mángano, M.G. and Buatois, L.A. 2017b. Ichnostratigraphy of the EdiacaranCambrian boundary: new insights on lower Cambrian biozonations from the Soltanieh Formation of northern Iran. Journal of Paleontology, 91 (6), 1178-1198.

Stöcklin, J. 1961. Lagoonal Formations and Salt domes in East Iran. Iranian Petrol. Inst. Bull., 3, 29-46. 
Stöcklin, J. 1968. Structural history and tectonics of Iran. A review.-Bull Amer. Assoc. PetrolGeol., 52, 1229-1258, Tulsa.

Stöcklin, J. 1972. Iran central, septentrional et oriental (en collaboration avec les géologues du Service Geologique de 1'Iran). Lexique Stratigr. Intern., 3 (fasc. 9b), Iran:1-283, Paris.

Stöcklin, J. 1986. The Vendian-Lower Cambrian Salt Basins of Iran, Oman, and Pakistan: Stratigraphy, Correlations, Paleogeography. Sciences de la Terre, Memorie, 47, 329-345 Nancy.

Stöcklin, J., Ruttner, A. and Navavi, M. 1964. New data on the Lower Paleozoic and Precambrian of North Iran. Geological Survey of Iran, Report 1, 13 p.Tucker, M.E. 1985. Shallow-marine carbonate facies and facies models. Geological Society, London, Special Publications, 18, 147-169.

Tucker, M.E. 1985. Shallow-marine carbonate facies and facies models. Geological Society, London, Special Publications, 18, 147-169.

Turniak, K., Mazur, S. and Wysoczanski, R. 2000. SHRIMP zircon geochronology and geochemistry of the Orlica-Śnieżnik gneisses (Variscan belt of Central Europe) and their tectonic implications. Geodinamica Acta, 13, 1-20.

Vaziri, S.H., Majidifard, M.R. and Laflamme, M. 2018. Diverse Assemblage of Ediacaran fossils from Central Iran. Scientific Reports, 8: 5060, doi: 10.1038/s41598-018-23442-y.

Vickers-Rich, P., Solemani, S., Farjandi, F., Zand, M., Linnemann, U., Hofmann, M., Wilson, S.A., Cas, R. and Rich, T.H. 2017. A preliminary report on new Ediacaran fossils from Iran. Alcheringa: An Australasian Journal of Paleontology, doi: 10.1080/3115518.2017.1384061.

Yaghubpur, A. and Mehrabi, B. 1997. Kushk Zinc-Lead deposit, a typical black-shale-hosted deposit in Yazd state, Iran. Journal of Science, I.R. Iran, 8 (2), 117-126. 


\section{Figure captions:}

Figure 1: Structural framework of Iran showing major tectonic plates and associated boundaries (A) and the location of study areas in the Bafq and Behabad regions, Central Iran (B).

Figure 2: Stratigraphic section of the Kushk Series in the Kushk (Bafq) and Chahmir (Behabad) areas, Central Iran

Figure 3: Field photographs and photomicrographs under polarized light (Scale bars $100 \mu \mathrm{m})$ of the Kushk Series. (A) Kushk area, showing black calcareous shale (host of zinc-lead deposit), view to the north. (B) Rhyolite and sandy dolomitic limestone of sub-units $1 \& 2$, Kushk area. (C) Porphyritic rhyolite of sub-unit 1. (D) Sandy dolomitic limestone, microdiorite and black calcareous shale of sub-units 2-5, Kushk area, view to the northeast. (E) Sandy crystalline dolomitic limestone of sub-unit 2. (F) Microdiorite of sub-unit 4. (G) Black calcareous shale of sub-unit 5, Kushk area, view to the northwest.

Figure 4: Field photographs and photomicrograph under polarized light (Scale bar $100 \mu \mathrm{m})$ of the Kushk Series. (A) Black pyritic shale of sub-unit 5, Chahmir area. (B) Organic matter in the black calcareous shale of sub-unit 5, Kushk area. (C-E) Ediacaran fossil-bearing gray argillaceous shale of sub-unit 6 (C, D): Chahgaz locale (Kushk), views to the northeast and north; (E) Wedge locale (Kushk), view to east. (F) Showing sub-units 6 - 11, Kushk area, view to the south. $(\mathbf{G}, \mathbf{H})$ Red argillaceous, siliceous siltstone of sub-unit 7, Kushk area. 
Figure 5: Field photographs and photomicrographs under polarized light (Scale bars $100 \mu \mathrm{m})$ of the Kushk Series. (A) Alternating siliceous dolomite and shale of sub-unit 8, tuff of subunit 9 and alternating siliceous dolomite and shale of sub-unit 10, Kushk area. (B) Medium crystalline siliceous dolomite of sub-unit 8, Kushk area (C) Green tuff of sub-unit 9 and, alternating siliceous dolomite and tuffaceous shale of sub-unit 10, Wedge locale (Kushk), view to the northwest. (D) Dolomitized argillaceous crystal-lithic tuff of sub-unit 9. (E) Alternating siliceous dolomite and shale of sub-unit 10, Kushk area. (F) Medium crystalline siliceous dolomite of sub-unit 10. (G) Gray cherty siliceous dolomite of sub-unit 11, Kushk area. (H) Finely to medium crystalline siliceous dolomite of sub-unit 11.

Figure 6: (A, B) Black calcareous shale of sub-unit 5 (host of lead-zinc deposit), Chahmir area, "A" view to the south. (C) Pyritic shale of sub-unit 5, Chahmir area. (D, E) Ediacaran fossil-bearing gray argillaceous shale and siltstone of sub-unit 6, Chahmir area. (F) Ediacaran fossil-bearing gray argillaceous shale of sub-unit 6, Darehdehu area, view to the northwest. (G) Shale of sub-unit 5, siliceous tuff of sub-unit 9 and Aghda limestone, Chahmir area, view to the northeast. (H) Siliceous tuff of sub-unit 9 and red sandstone of the Dahu Series, Chahmir area, view to the southwest. 
Figure 7: Field photographs and photomicrographs under polarized light (Scale bars $100 \mu \mathrm{m})$ of the Kushk Series. (A) Light-gray, siliceous dolomite of sub-unit 12, Kushk area, view to the southwest. (B) Medium coarsely crystalline dolomite of sub-unit 12. (C) Light-cream rhyolite of sub-unit 13, Kushk area. (D) Rhyolite of sub-unit 13. (E) Alternating light-cream rhyolite and green rhyolitic to rhyodacitic tuff of sub-unit 13, Kushk area, view to the southwest. (F) Green rhyolitic to rhyodacitic tuff of sub-unit 13, Kushk area. (G) Rhyodacitic crystal tuff of sub-unit 13, impregnated with iron oxide. (H) Rhyolitic crystal tuff of sub-unit 13, Kushk area.

Figure 8: Sedimentary succession of the Kushk Series in the Kushk area, Bafq, Central Iran

Figure 9: Plate-tectonic reconstruction of Gondwana at the end of Neoproterozoic time (544 Ma; modified from Kusky et al. 2003) showing the position of Iran in the Proto-Paleotethys passive margin of northern Gondwana.

Figure 10: Sedimentary environment model of the Kushk Series in Bafq region, Central Iran, showing a homoclinal ramp, SL: seal level; FWWB: fair-weather wave base; SWB; storm wave base. 

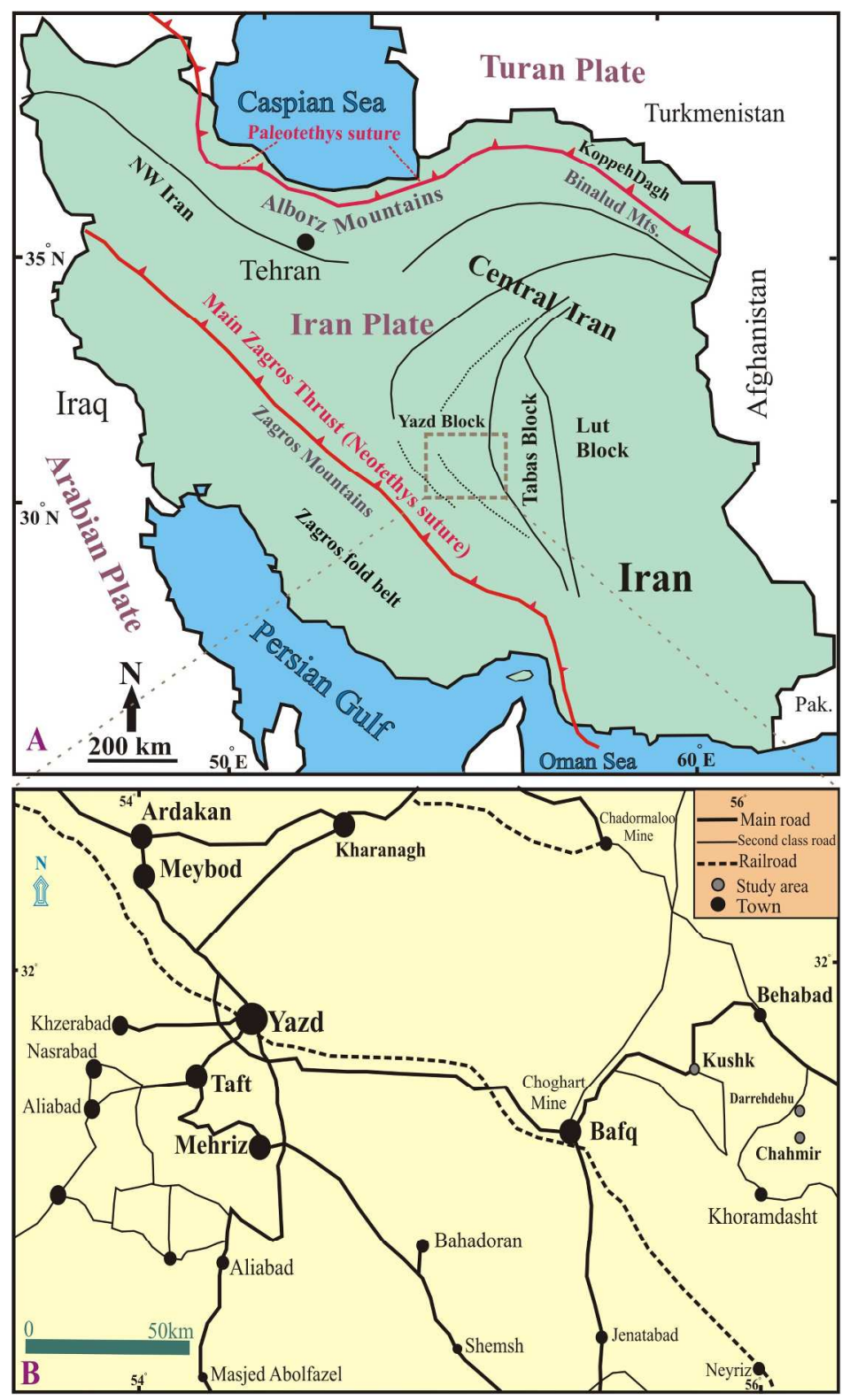

Figure 1: Structural framework of Iran showing major tectonic plates and associated boundaries $(A)$ and the location of study areas in the Bafq and Behabad regions, Central Iran (B).

$160 \times 267 \mathrm{~mm}(300 \times 300 \mathrm{DPI})$ 


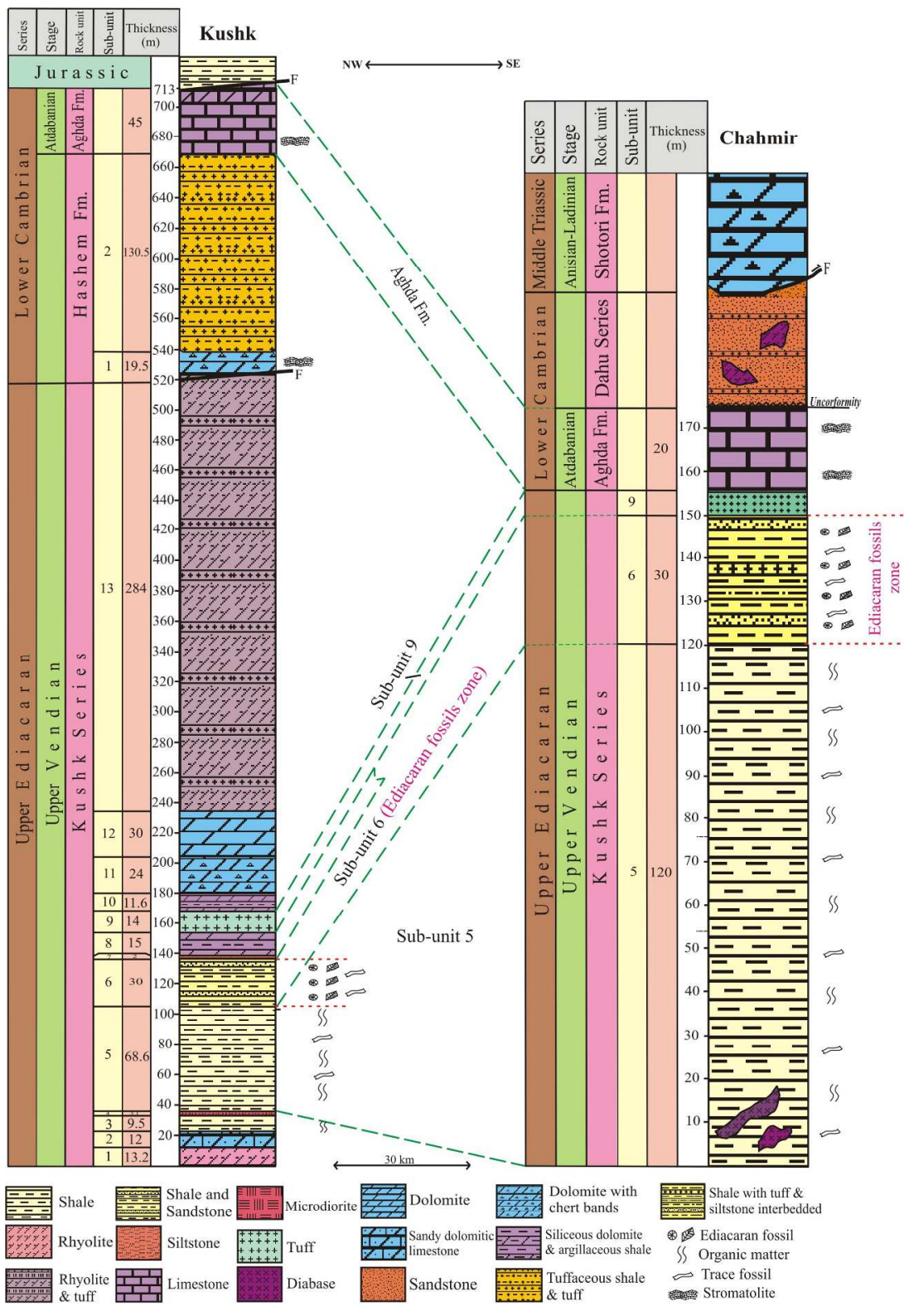

Figure 2: Stratigraphic section of the Kushk Series in the Kushk (Bafq) and Chahmir (Behabad) areas, Central Iran

$188 \times 271 \mathrm{~mm}(300 \times 300 \mathrm{DPI})$ 

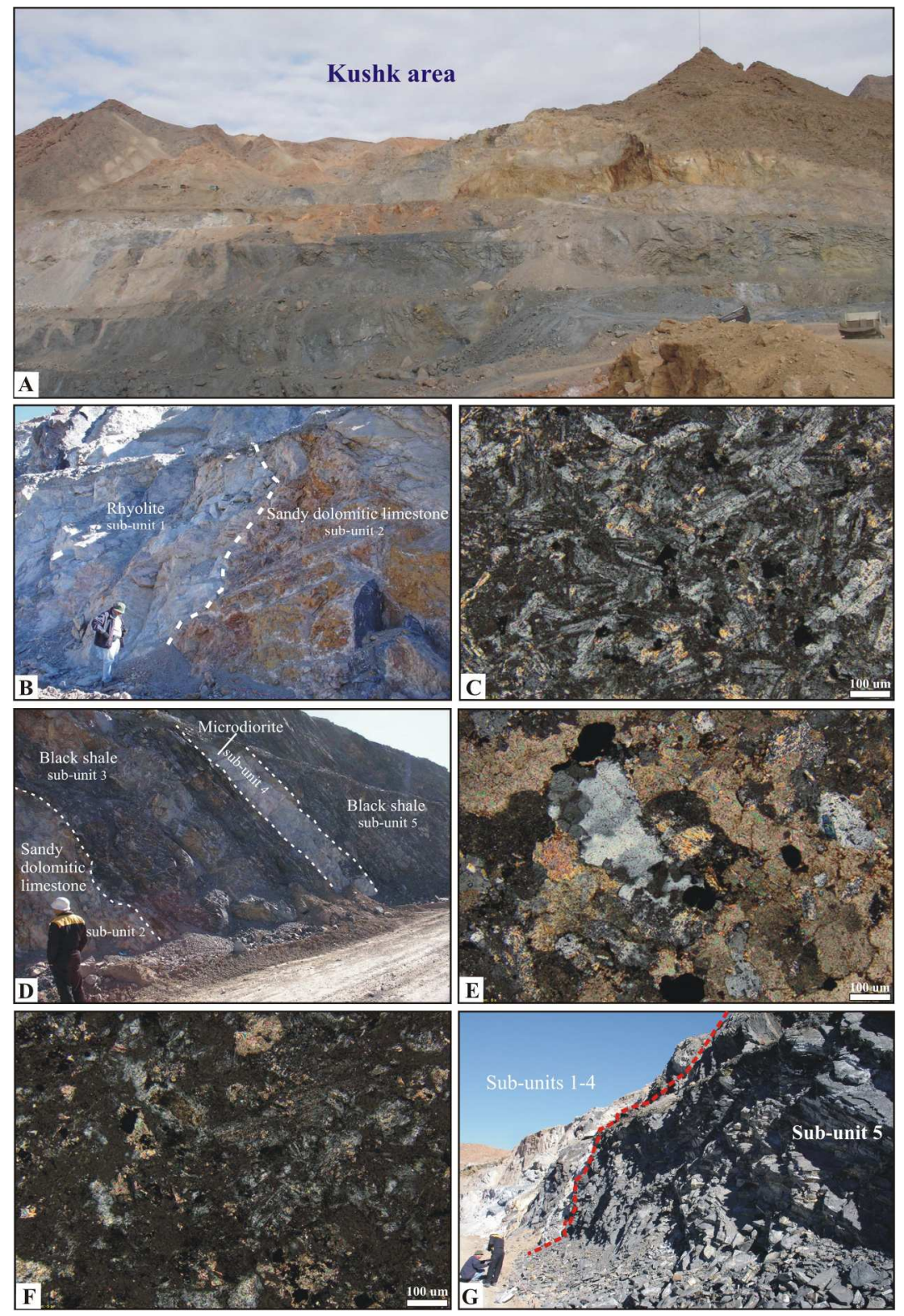

Figure 3: Field photographs and photomicrographs under polarized light (Scale bars $100 \mu \mathrm{m}$ ) of the Kushk Series. (A) Kushk area, showing black calcareous shale (host of zinc-lead deposit), view to the north. (B) Rhyolite and sandy dolomitic limestone of sub-units 1 \& 2, Kushk area. (C) Porphyritic rhyolite of sub-unit 1. (D) Sandy dolomitic limestone, microdiorite and black calcareous shale of sub-units 2-5, Kushk area, view to the northeast. (E) Sandy crystalline dolomitic limestone of sub-unit 2. (F) Microdiorite of sub-unit 4. (G) Black calcareous shale of sub-unit 5, Kushk area, view to the northwest. 

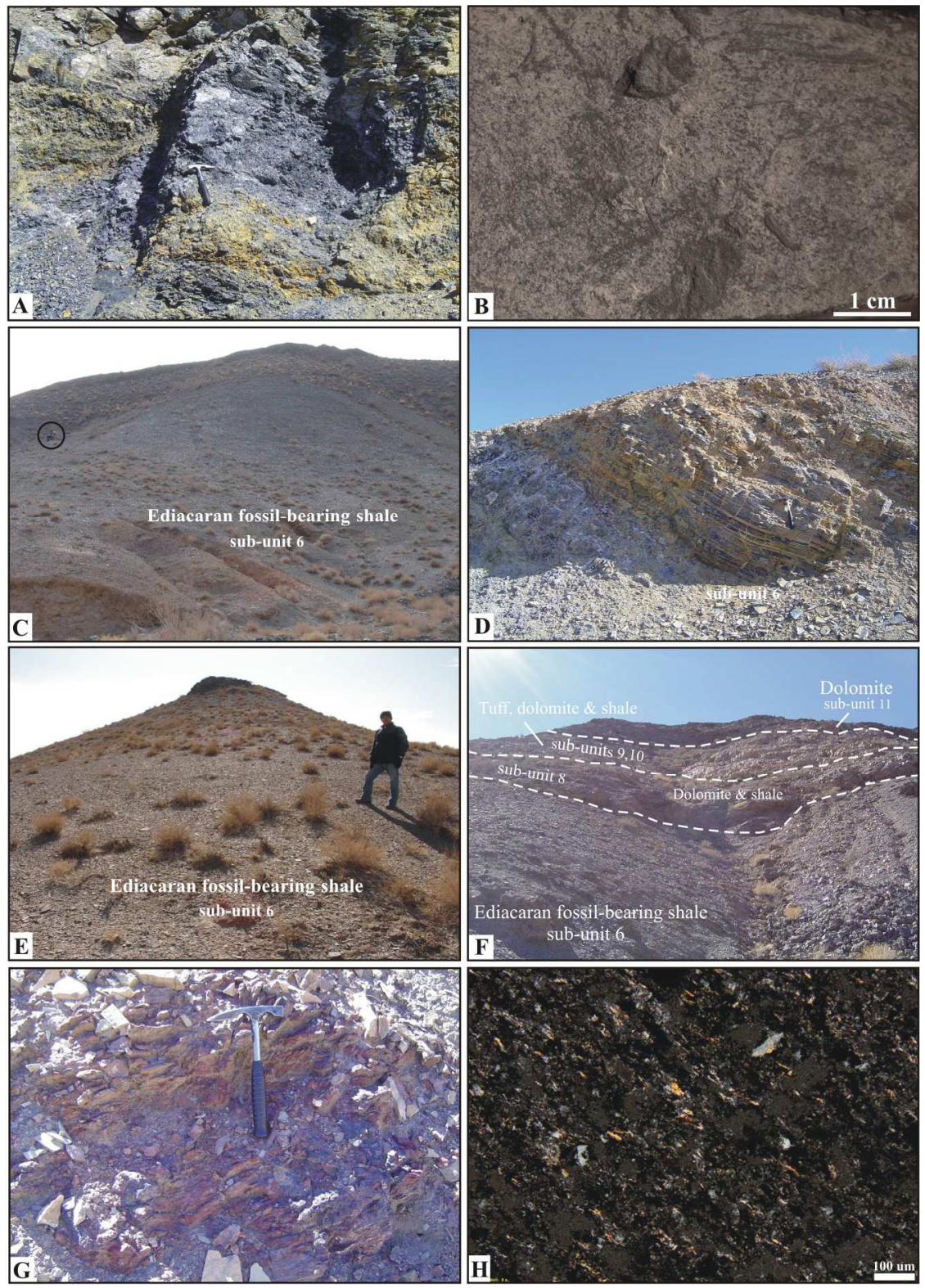

Figure 4: Field photographs and photomicrograph under polarized light (Scale bar $100 \mu \mathrm{m}$ ) of the Kushk Series. (A) Black pyritic shale of sub-unit 5, Chahmir area. (B) Organic matter in the black calcareous shale of sub-unit 5, Kushk area. (C-E) Ediacaran fossil-bearing gray argillaceous shale of sub-unit 6 (C, D): Chahgaz locale (Kushk), views to the northeast and north; (E) Wedge locale (Kushk), view to east. (F) Showing sub-units $6-11$, Kushk area, view to the south. (G, H) Red argillaceous, siliceous siltstone of subunit 7, Kushk area.

$166 \times 232 \mathrm{~mm}(300 \times 300 \mathrm{DPI})$ 

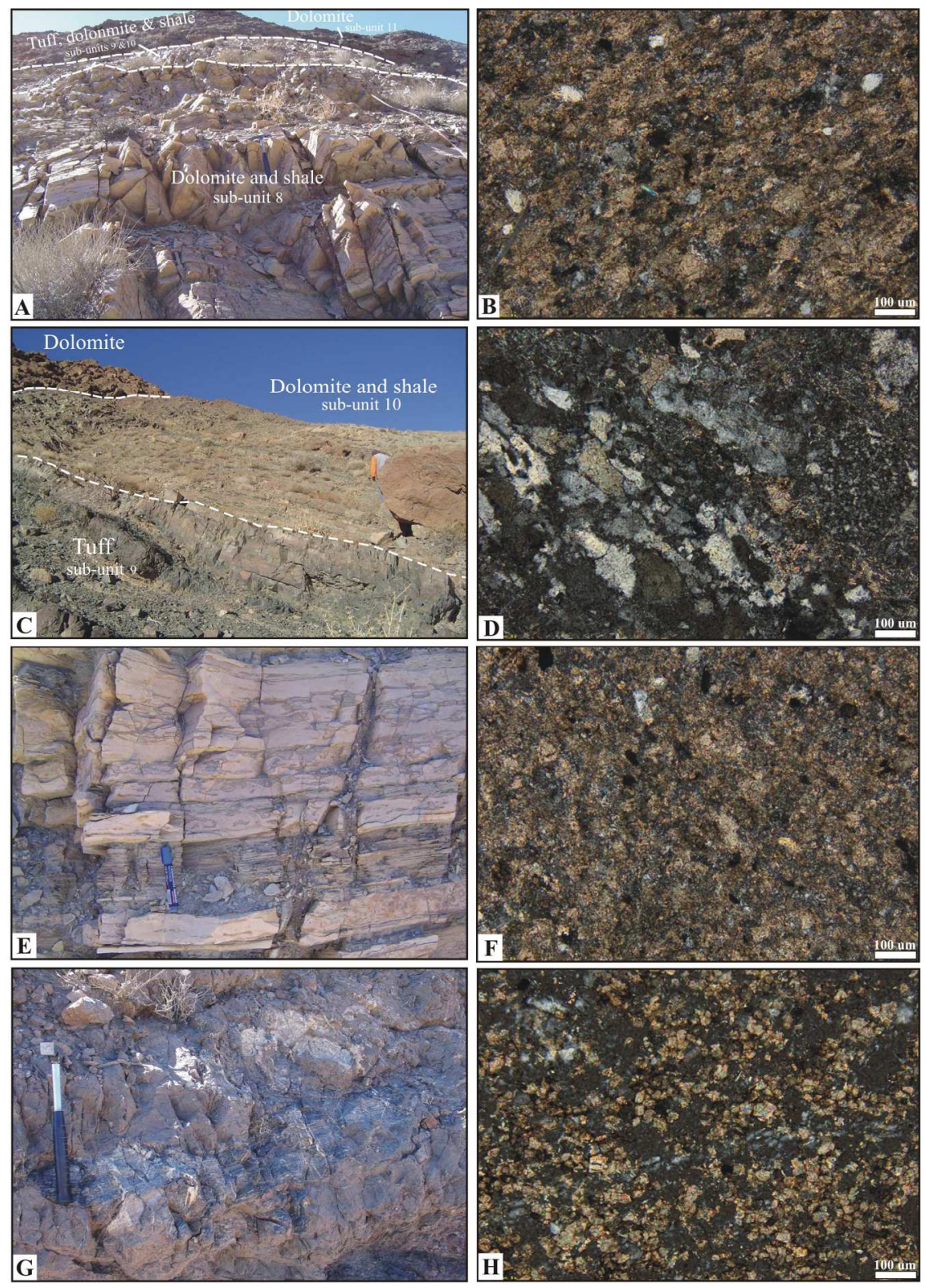

Figure 5: Field photographs and photomicrographs under polarized light (Scale bars $100 \mu \mathrm{m}$ ) of the Kushk Series. (A) Alternating siliceous dolomite and shale of sub-unit 8, tuff of sub-unit 9 and alternating siliceous dolomite and shale of sub-unit 10, Kushk area. (B) Medium crystalline siliceous dolomite of sub-unit 8 , Kushk area (C) Green tuff of sub-unit 9 and, alternating siliceous dolomite and tuffaceous shale of sub-unit 10, Wedge locale (Kushk), view to the northwest. (D) Dolomitized argillaceous crystal-lithic tuff of sub-unit 9. (E) Alternating siliceous dolomite and shale of sub-unit 10, Kushk area. (F) Medium crystalline siliceous dolomite of sub-unit 10. (G) Gray cherty siliceous dolomite of sub-unit 11, Kushk area. (H) Finely to medium crystalline siliceous dolomite of sub-unit 11 .

$166 \times 232 \mathrm{~mm}(300 \times 300$ DPI $)$ 

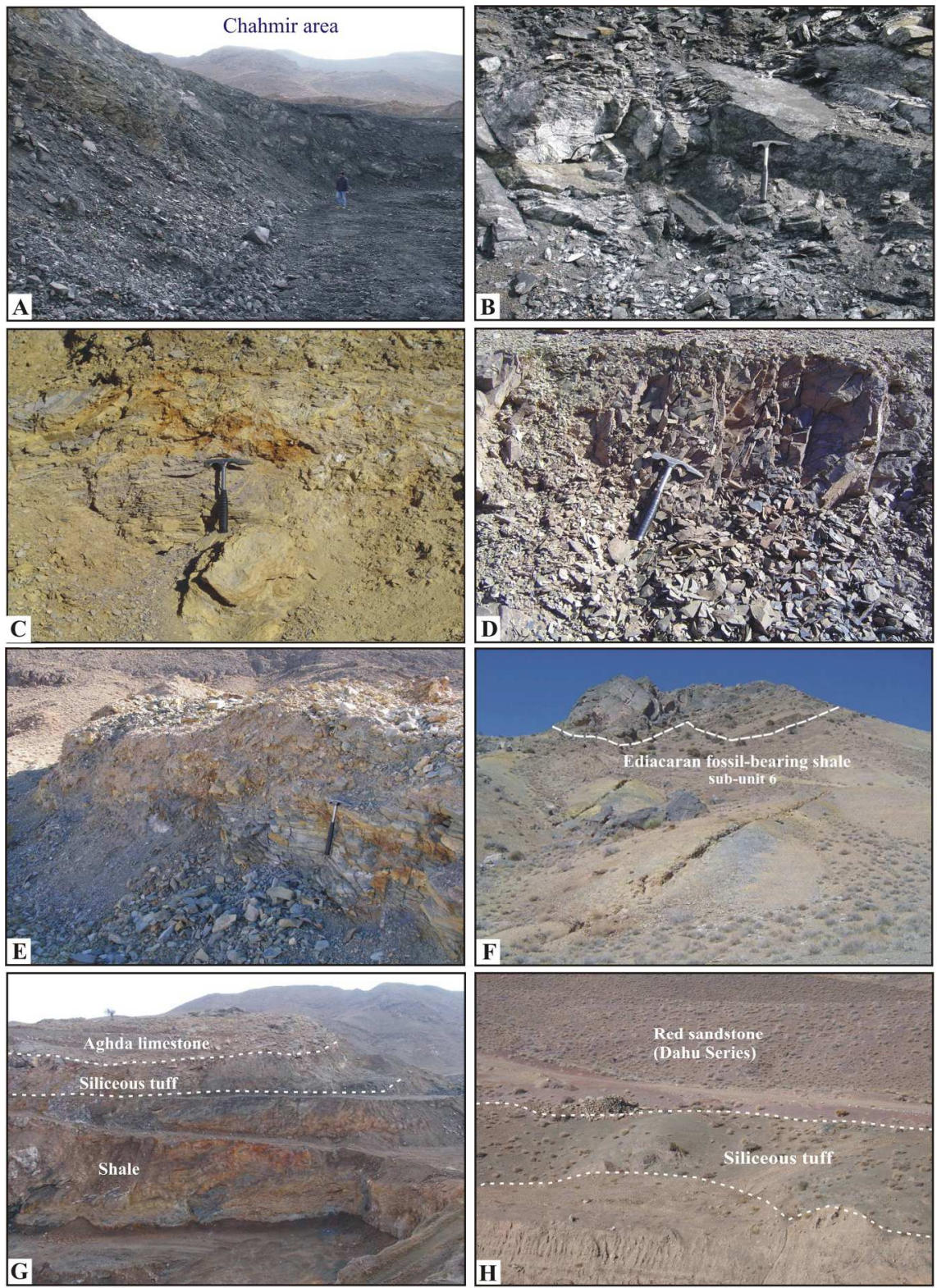

Figure 6: (A, B) Black calcareous shale of sub-unit 5 (host of lead-zinc deposit), Chahmir area, " $A$ " view to the south. (C) Pyritic shale of sub-unit 5, Chahmir area. (D, E) Ediacaran fossil-bearing gray argillaceous shale and siltstone of sub-unit 6, Chahmir area. (F) Ediacaran fossil-bearing gray argillaceous shale of subunit 6, Darehdehu area, view to the northwest. (G) Shale of sub-unit 5, siliceous tuff of sub-unit 9 and Aghda limestone, Chahmir area, view to the northeast. (H) Siliceous tuff of sub-unit 9 and red sandstone of the Dahu Series, Chahmir area, view to the southwest.

$168 \times 232 \mathrm{~mm}(300 \times 300 \mathrm{DPI})$ 

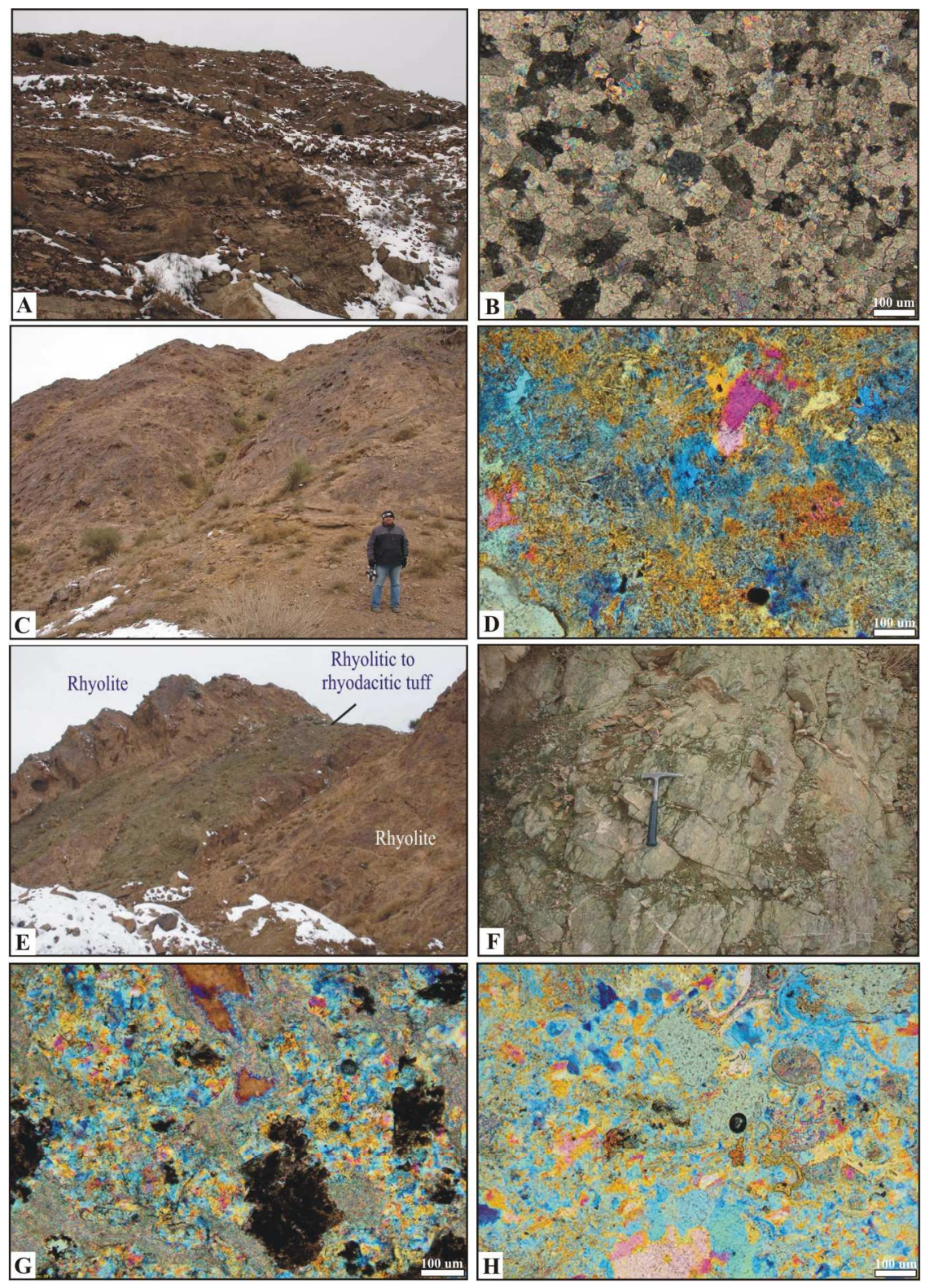

Figure 7: Field photographs and photomicrographs under polarized light (Scale bars $100 \mu \mathrm{m}$ ) of the Kushk Series. (A) Light-gray, siliceous dolomite of sub-unit 12, Kushk area, view to the southwest. (B) Medium coarsely crystalline dolomite of sub-unit 12. (C) Light-cream rhyolite of sub-unit 13, Kushk area. (D) Rhyolite of sub-unit 13. (E) Alternating light-cream rhyolite and green rhyolitic to rhyodacitic tuff of sub-unit 13, Kushk area, view to the southwest. (F) Green rhyolitic to rhyodacitic tuff of sub-unit 13, Kushk area. (G) Rhyodacitic crystal tuff of sub-unit 13, impregnated with iron oxide. (H) Rhyolitic crystal tuff of sub-unit 13. 


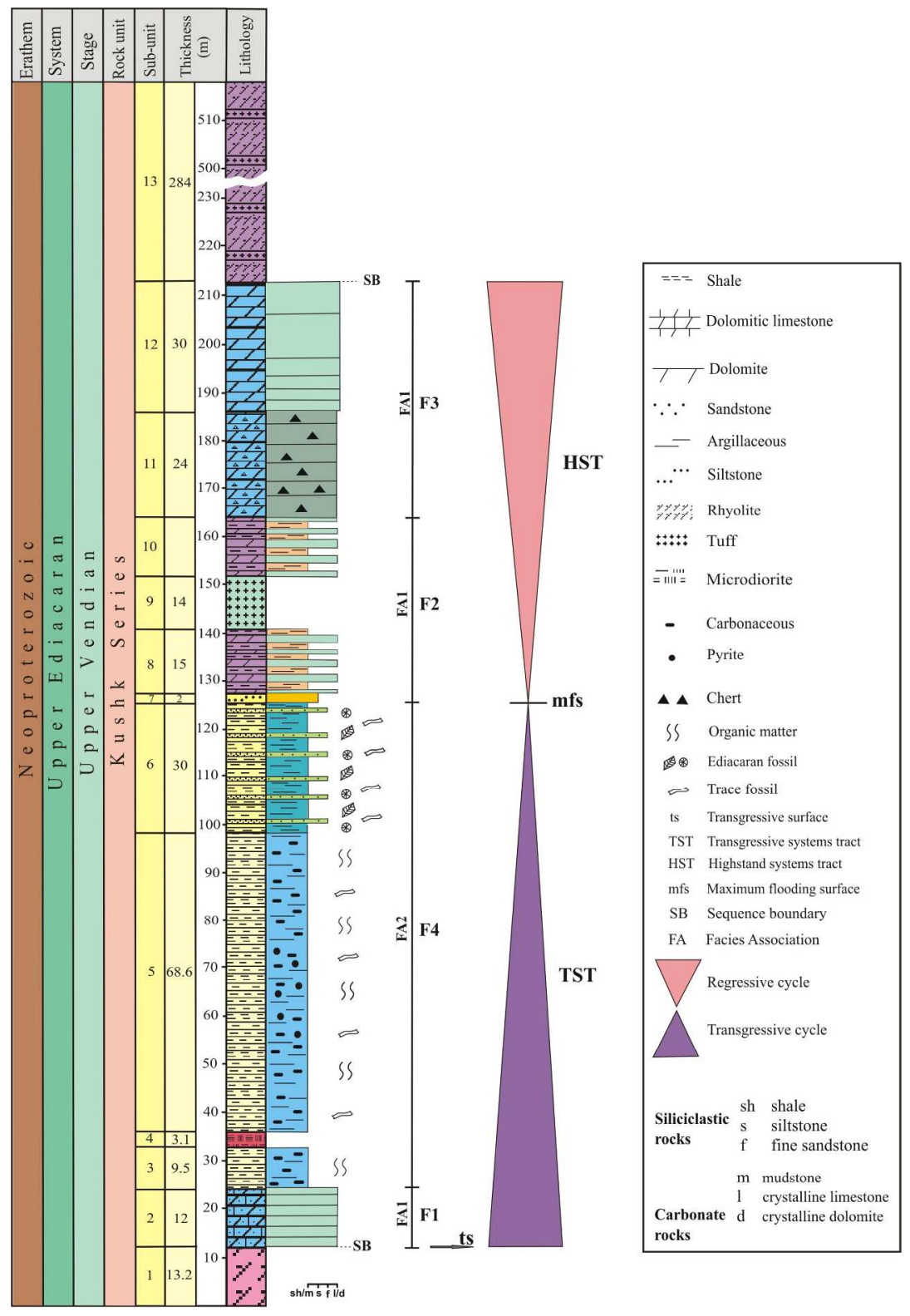

Figure 8: Sedimentary succession of the Kushk Series in the Kushk area, Bafq, Central Iran $185 \times 270 \mathrm{~mm}(300 \times 300 \mathrm{DPI})$ 


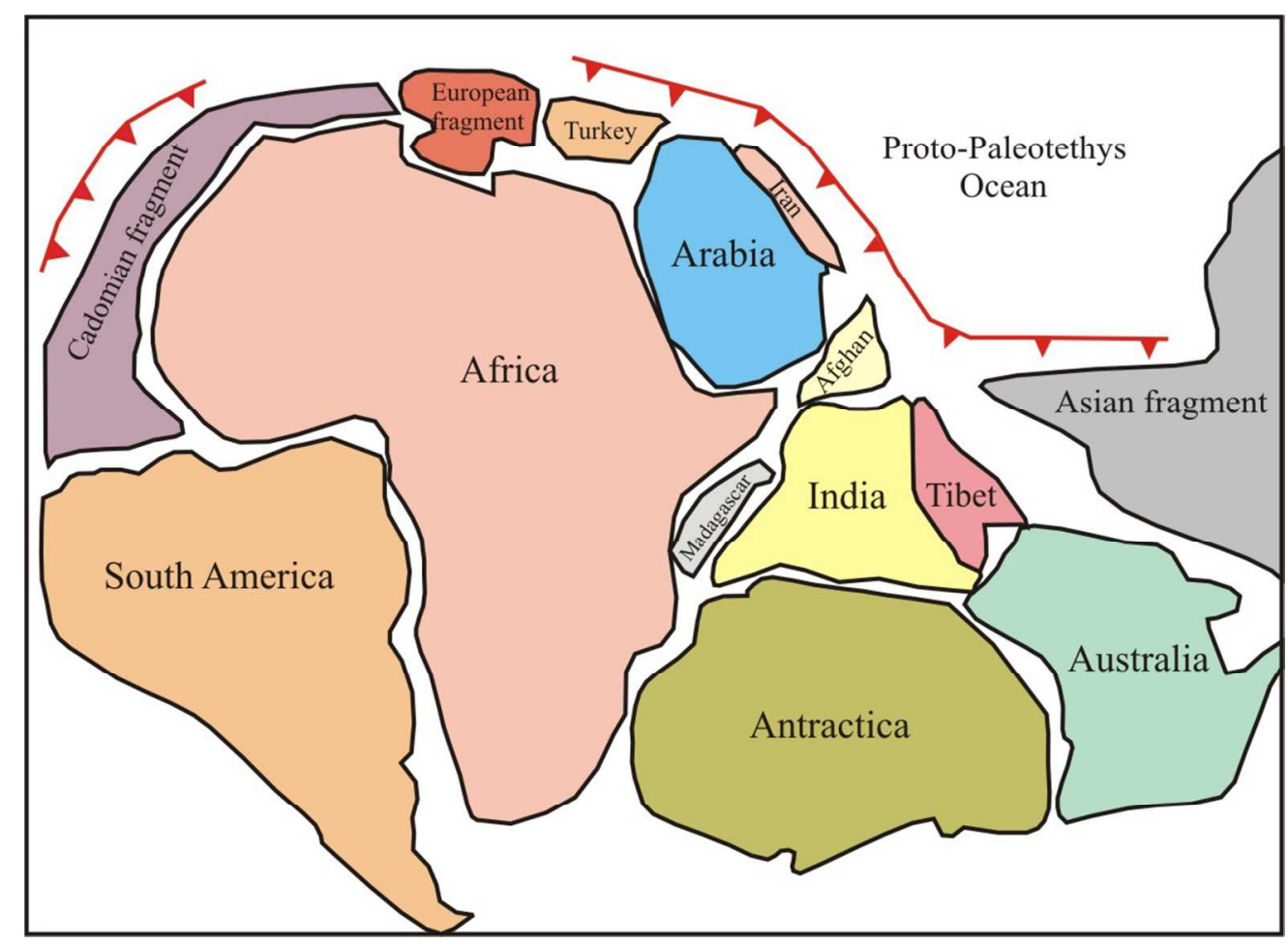

Figure 9: Plate-tectonic reconstruction of Gondwana at the end of Neoproterozoic time (544 Ma; modified from Kusky et al. 2003) showing the position of Iran in the Proto-Paleotethys passive margin of northern Gondwana.

$103 \times 75 \mathrm{~mm}(300 \times 300$ DPI $)$ 


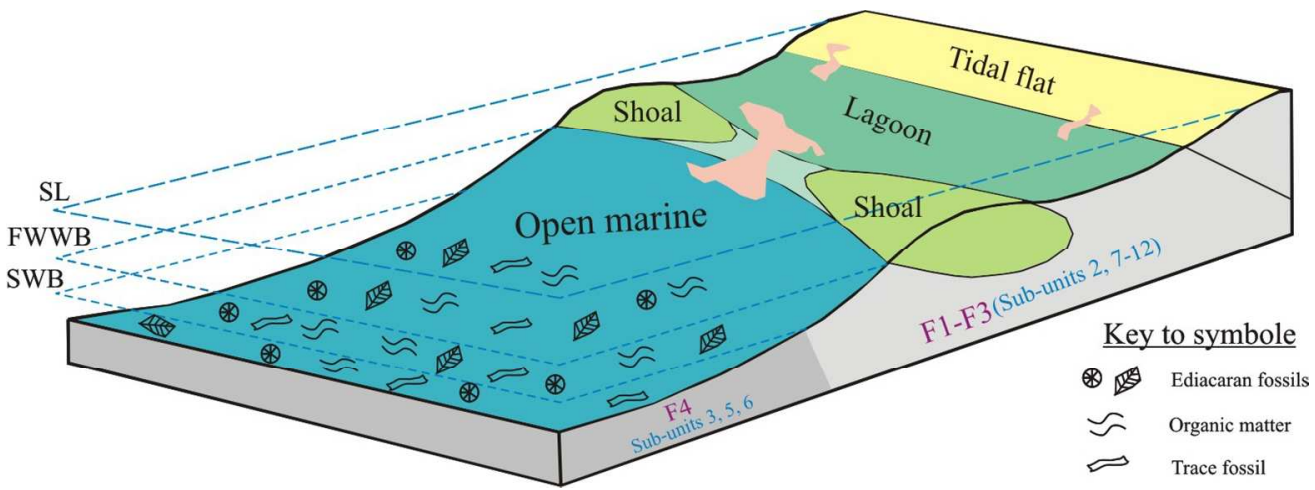

Figure 10: Sedimentary environment model of the Kushk Series in Bafq region, Central Iran, showing a homoclinal ramp, SL: seal level; FWWB: fair-weather wave base; SWB; storm wave base.

$135 \times 49 \mathrm{~mm}(300 \times 300 \mathrm{DPI})$ 